\title{
THE IMPLEMENTATION OF POVERTY REDUCTION PROGRAMS THROUGH PNPM MANDIRI-PROSPEK: A STUDY CONDUCTED IN SOUTH JAYAPURA SUB-DISTRICT, PAPUA
}

\author{
Bajari Abner Herry*, Hakim Abdul, Mardiyono, Hanafi Imam \\ Doctoral Degree Program in Administrative Science, Faculty of Administrative Science, \\ University of Brawijaya, Indonesia \\ *E-mail: humas@ub.ac.id
}

\begin{abstract}
Contemporary phenomenon of poverty was always interested to be studied, given that the effort of poverty alleviation through various types of community empowerment program still found many deficiencies in terms of both the process and the implementation of poverty alleviation policy. This research aimed to study the phenomenon of reality, normative and theoretical gap of poverty alleviation policy implementation through Mandiri National Community Empowerment Program and Strategic Village Economic and Institutional Development Program (PNPM Mandiri-Prospek). This research was intensively carried out for two months using naturalistic inquiry approach sourced from informants, circumstances, and documents. This research was conducted in one sub-district and two villages, i.e. Tahima Soroma and Tobati villages. Data collection techniques used to conduct this research was observation, interview, and documentation science. Output program has been in accordance with the needs of target group representing that output program could be utilized properly. The implementation of community empowerment program through PNPM Mandiri-Prospek has been conducted in accordance with the application of empowerment principle/values.
\end{abstract}

\section{KEY WORDS}

Implementation, poverty reduction, policies, community, empowerment, programs.

Global leaders have agreed on the purpose of global development from "Millennium Development Goals" (MDGs) in September 2015 to "Sustainable Development Goals" (SDGs) with the global development sustainability purpose under the development indicator of poverty, education, environment, and health and gender equality. Indonesia is especially expected to overcome the complexity of human and development problem so that in the future there will no one who leaves behind. In between the current national issues, Indonesia is surely not allowed to forget its commitment to the SDGs performance. Indonesia also takes part to declare that development agenda in New York, United States. SDGs' contain sustainable development goals, has a particular deadline and a measured target that has to be achieved at the end of 2030. SDGs implementation becomes country's commitment to the Indonesian and Indonesia's commitment to the global community (UN, 2015).

As written in the Outcome Document Transforming Our World: The 2030 Agenda for Sustainable Development, the goal to end poverty becomes the "major" goal of 17 goals agreed in Sustainable Development Goals (SDGs) program. The first goal of those 17 Sustainable Development Goals is "end poverty in all its forms of everywhere." Even though Indonesia has become G-20 (Government-20) member, that is 20 biggest countries in the world which dominate $75 \%$ of world trade and $2 / 3$ of the total global citizen, but Indonesia is still as the lower-middle-income-country (income per capita US\$1.046-4.125). It means the major factor of Indonesia's participation in G-20 is still because of the population so that it is not surprising if poverty problem still becomes the major problem. (UN, 2015).

Indonesia through the 1945 Constitution of Article 34 paragraph (1) stipulates that " Impoverished persons and abandoned children shall be taken care of by the State", and paragraph (2) "The state shall develop a system of social security for all of the people and shall empower the inadequate and underprivileged in society in accordance with human 
dignity". It is emphasized by Law of The Republic of Indonesia Number 11 of 2009 on Social Welfare, article 20 letter a stipulates that; one of the goals of poverty alleviation is to increase capacity and to develop the poor's basic skills and business skill. That Law of The Republic of Indonesia is followed up by Presidential Regulation Number 15 Year 2010 on the Acceleration of Poverty Alleviation. Poverty Alleviation is a policy and local government program conducted systematically, planned, and synergized with the business world and community to decrease total poor community in order to increase the degree of community welfare. Furthermore, Giddens (1984) stated that the relationship between the actor and structure has a mutual relationship so that brings them into duality. For that matter, an actororiented approach is used to see how poor family (agent) or poor community (a group of agents) respond various existing conditions of policy in considering interface among them. Relationship dynamic among the actors is expected able to explain why poverty alleviation policy along this time is not successful yet to touch the poor community, thus, the problem of participation and empowerment principle implementation needs to get attention.

Suharto (2006) mentioned that there are two grand theories on poverty, i.e. neoliberalism paradigm and democracy-social paradigm. Neo-liberalism theory is rooted in classical politic written by Thomas Hobbes, John Lock, and John Stuart Mill. According to the neo-liberalism view, poverty is an individual problem caused by the weakness or individual choice. The country only acts as a "night keeper" and the strategy applied is "residual" that is through market strength and economic development accompanied by assistance provision to the poor directly and selectively.

In Indonesia's context, thinking pattern and the practice of development can be divided into three models (Mochtar \& MacAndrew, 1993). Those models are; firstly, approach that priorities political consideration which emphasizes on the state's role and bureaucrats as the main actor of the development or also known as Politics as Commander (PSP); secondly, approach that prioritize the role of entrepreneur and corporate known as Economy as Commander (ESP); and thirdly is poverty handling by helping community to find its own strength or known as Human as Commander (MSP). Those three ideas are illustrated by Michtar \& Mac Andrew (1993) in table 1 below:

Table 1 - Mindset and Development Practice in Indonesia

\begin{tabular}{|c|c|c|c|}
\hline Description & Politics as Commander & Economy as Commander & Human as Commander \\
\hline Actor & State (Bureaucrats) & Market (Entrepreneur) & Local Community (Citizen) \\
\hline Mechanism & Political Strength & Economic Strength & Community Strength \\
\hline Ideology & Statism/Conservative & Liberalism & Populist \\
\hline
\end{tabular}

Source: Mochtar Mas'oed (1993).

Public administration organizer or participation-based governance can be ideologically said an antithesis of market-based approach (Peters, 2001). Poor community or the poor as the policy target of poverty alleviation must be heard since whatever happened they are the one who will make a decision for themselves and that will determine their future life (Wahab, 2002; Narayan, 2002). At the micro-level, the respond and the behavior of the poor as the actor is influenced by anything that according to them is most beneficial and enables or commonly called as notion of rationality. Poor community as the actor is actually not a passive group but in opposite is a group which actively takes an action in an intervention and will determine the success (Ploeg \& Long, 1994). Poor community also tries to play a role and influence that is through the effort of counter-labeling from poor community and this can be identified as a struggle. That understanding is needed in accordance with the characteristic or in the social context is institutional and local politics. Therefore, Narayan (2002) proposed that some efforts of community empowerment as one of the steps of poverty alleviation are conducted by applying principles (values) of empowerment including aspect, access to information, inclusion \& participation, accountability and local institutional capacity. Narayan's idea is in accordance with the discussion that has been proposed by World Bank in 2012 in which the access to information, involvement (participation), 
accountability, and institutional capacity in the local area is truly needed in terms of community empowerment.

This research shows that the real condition of the poor community for Papua Province scale in Indonesia can be described below:

According to the regional type, the poor community is concentrated in the rural area, in September 2015 there was $37.34 \%$ poor community living in the rural area while 3.61 present lived in the urban area. Poverty Line (PL) in the urban area in September 2015 was by Rp. 445,057 (US\$ 31.82) higher than Poverty Line of rural area that reached up to Rp. 392,446 . That is the cost to fulfill the basic needs for food not indicating that the food in the urban area is always better than in rural area. During the period of March 2015-September 2015, Poverty Gap Index-P1 and Poverty Severity Index-P2 tended to increase. This indicates that the average expenditures of the poor community tend to out of poverty line and inequality of poor community expenditure is also bigger (BPS, 2016).

Phenomenon description related to the poverty problem above needs "way out as the trajectory" in form of public policy that aims to determine the direction of development which will be conducted in terms of poverty alleviation. However, this policy has a risk to fail since its bad execution or bad policy, or even that policy has a bad luck. For that matter, Mazmanian \& Sabatier (cited by Wahab, 2002) have investigated that learning the problem of policy implementation means trying to understand what has been done after the program finished. It means that it does not only influence institutional behavior that responds to the target group but also consider various strengths of politics, economics and social that influences the implementation of state policy. Furthermore, implementation success a policy will be determined by various aspects and factors, and each aspect or factor relates each other. The success of the policy implementation is truly determined by the implementation model which is able to guarantee problem complexity which will be finished through particular policy. This implementation model is actually expected a model that is more operational so that able to explain causality among the aspect or factor related to policy (Sumaryadi, 2005). Edward III (1984) mentioned that there are four aspects or factors that influence implementation performance of a public policy, they are 1) Communication; 2) resources; disposition or attitudes; 4) bureaucratic structure. While Korten (1988) described that in terms of policy implementation, there are three elements of program execution, i.e. program itself, program execution, and target group.

According to the description of the poverty above, Provincial Government gives a solution of poverty alleviation through Strategic Village Economic and Institutional Development Program (PROSPEK) based on the Laws, Governor Regulation, Governor Decree, and Mayor's Decision Letter. That legal standing becomes an entry point of Papua Province Government and Jayapura city in terms of poverty alleviation. According to the description of that background so that the researchers are interested to conduct a study with the focuses: (1) program implementation of PNPM-MANDIRI PROSPEK in South Jayapura Sub-district, and (2) community empowerment implementation through the study of PNPM MANDIRI-PROSPEK in South Jayapura Sub-district, Papua Province.

\section{LITERATURE REVIEW}

Public Policy Implementation. The existence of a public policy is always followed-up by policy implementation. For that matter, implementation is a determining stage in the policy process Ripley \& Franklin (1982, as quoted by Tarigan, 2000). Policy implementation is an activity that is seemed after being issued an official guidance of a policy including input processing effort to produce output or outcomes for society. Policy implementation stage can be characterized and differentiated by a policy-making process. Policy-making is a process having bottom-up logical which means policy process is started by proposing aspiration, asking or support from society. While the implementation of a policy has a top-down logical which means as an alternative integration of abstract or macro policy alternative so that become a concrete action (Wibawa, 1994). Policy formulation that has been formed will not have a meaning if not being implemented. For that matter, success measurement of policy is 
in the implementation process. Adiwisata (cited by Tachjan, 2006) emphasized that policy implementation is an important thing. Public policy made will only be a "paper" if its implementation is failed. Furthermore, the success of public policy implementation does not only need rationality, but also implementer ability to understand and respond expectation developing in the society, in which public policy will be implemented.

Nugroho (2004) offered two options for public policy, i.e. (1) directly implement it in form of programs, and (2) through derivative policy formulation or integration of that public policy. Those two options above can be implemented well, it should also consider what and how the form of reality program is so that can fulfill public interest. Policy implementation activity management can be arranged in orderly through the following stages: 1) strategy implementation (pre-implementation), organizing, 3) movement and leadership, 4) controlling. Moreover, understanding the implementation of policy means trying to understand what happened next after a program is being executed or formulated. Mazmanian and Sabatier (as quoted by Wahab, 2002) has explained that implementation means understanding what truly happened after a program stated applicable or formulated is a focus of policy implementation consideration, that is circumstances and state activities that cover both effort to administer and bring real impact to the society or circumstances can be meant that policy implementation can be seen as a process of policy implementation. While the objective of the most basic implementation study is learning how the performance of a public policy, and learning critically factors that influence a policy to achieve a policy goal (Effendi, 1993).

In a policy process, there will always be a possibility of the difference between what expected and planned by the decision maker and the reality (condition sin qua nun) also known as implementation gap Dunsire (1978). The size of implementation gap depends on the implementation capacity that is an ability of an organization/actor to execute policy decision as it so that there is a guarantee that the goal or target has been set in the formal document can be achieved. Government policy that has been set in its implementation contains failure risk. Hogwood and Gunn (1984) divided policy failure into two categories, i.e. (1) not implementation; and (1) unsuccessful implementation). Not implementation policy is caused by; (1) involved parties in the implementation process do not want to cooperate; (2) working not efficiently; (3) working halfheartedly; (4) not completely master the problem; (5) problem faced beyond the ability. On the other hand, unsuccessful implementation is caused by; (1) bad execution; (2) bad policy; (3) bad luck.

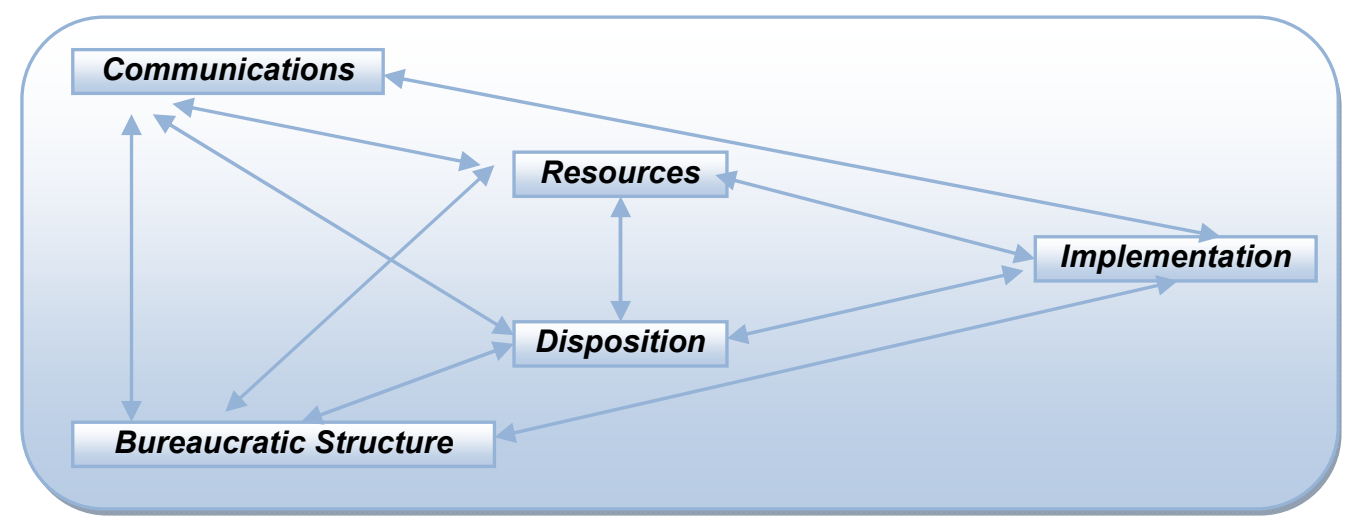

Figure 1 - Policy Implementation Model (Edward III, 1984)

Public policy implementation can be seen from several perspectives or approaches. One of them is implementation problems approach introduced by Edwards III (1984). The approach to implementation problem is firstly proposing 2 main questions, i.e. (1) what does the factor that supports the success of policy implementation? (2) What does the factor that inhibits the success of policy implementation? Moreover, there is four variables that influence public policy implementation performance, i.e. (1) communication; (2) resources; (3) 
Disposition or attitudes; (4) bureaucratic structure. Policy implementation study approach, its abstract question is started from how the pre-condition to success public policy and what the main obstacle to public policy success. Detail information can be seen in Figure 1.

According to the figure above, it can be meant that the success of policy implementation requires the implementer to understand what have to do. Every purpose and policy target has to be socialized to the target group so that will decrease the implementation distortion.

In relation to the human resources factor that influence implementation process of a policy, Mazmanian, and Sabatier as quoted by Subarsono (2005) made a categorization that policy implementation is understood through three different perspectives, i.e. decision maker, executing officials at the field and individual actor as the target group. Implementer's obedience is measured by considering the relevance of implementer behavior to the obligation carried out. Important sources in the implementation of policy meant to cover: 1) Staff must have the skill and ability to do the task, 2) Command, 3) Superior/boss's suggestion. In addition, there have to accuracy or propriety between the total staff needed and skill that has to be had to the task that will be done. The cost to pay operational of that policy implementation, relevant and adequate information on how the way to implement a policy, and the willingness or ability of various parties involved in the implementation of that policy. This is intended to make the implementer will not make a mistake on how the way to implement that policy.

Development Concept. Development theory in the social science can be divided into two big paradigms, i.e. modernization and dependence (Larain, 1994). Modernization paradigm covers macro theories on economic development and social change and micro theories on individual values that support change process. Dependence paradigm covers under-development and dependent development theories as well as world-system theory in accordance with Larrain's (1994) classification. While Tikson (2005) divided it into three classifications of development theory, i.e. modernization, under-development and dependent development. Those various paradigms bring some versions of the definition of development.

Development can be defined as an effort to be coordinated to create more official alternatives to every citizen to complete and achieve its humanism aspiration (Nugroho \& Dahuri, 2004). The first theme is coordination implicating on the needs of planning activity like that has been discussed previously. The second theme is the creation of a more official alternative. This can be defined that development should be diversity-oriented at all aspects of life. Any mechanism brings to the creation of trusted institutional and law which are able to play role efficiently, transparently, and fairly. The third theme is the most humanism aspiration; it means development must be oriented to the problem solving and the guidance of moral values and attitude. In relation to the development definition, some experts give various definitions of the planning. The term of development is possible to be translated into a different meaning by one and another, one region to another and one country to another. However, actually, there is an agreement that development is a process to do improvement (Bratakusumah \& Irawati, 2005).

According to Kuncoro (1997), the existing development theory still has not completely finished economic development activities in the region. For that matter, it is important to do a reformulation of a new paradigm of more comprehensive local economic development planning. It needs a synthesis of the existing various approaches so that can result in a new formulation on a new paradigm of economic development more completely. In the existing various ideas, there are some of the difference between old and new concept on development. Following identification conducted by Kuncoro (!997) so that the implementation can be used in Jayapura to evaluate or assess regional economic development that is going on now. One of the points that must be considered in order to apply more comprehensive regional economic development paradigm is how the process of economic identification will be more realistic. National Long-Term Development Plan (RPJMD) must line basic things to achieve the target, among other is the improvement of regional potential that can be conducted. While the fundamental points to compile 
identification of that local development economics are (a) the increase of local economics development rate (b) the increase of income per capita (c) the decrease of the poverty rate, and significant inequality.

Community Empowerment. According to Bevir (2007), the term of empowerment was firstly found in the introductory politics in the liberal community since 1960s. The struggle of human rights from black American, the appearing of feminism theory leans both on the empowerment idea of liberal democracy portrait as an incomplete thing and is not sufficient to care full rights of all citizens. Community empowerment actually refers to the term of empowerment in which the effort to actualize potential owned by society, community empowerment concept covers the definition of community development, community-based development, and community-driven development. Community empowerment paradigm comes as a response to the reality of the gap that is not completely solved especially among the society in the rural area. Isolated and Underdeveloped Area Rural community seems like being a reflection of poverty because of several factors, $70 \%$ of the poor community in Indonesia live in rural area, one of the solutions for central government or local government is community empowerment-based innovation. Empowerment is actually putting society on the object referred.

The government as the "agent of change" can apply the policy of poor community empowerment with three directions, i.e. enabling, empowering, and protecting. Enabling means creating a situation or climate that enables community potential to develop. While empowering aims to strength potential or power owned by the citizen by applying real steps, that is by accommodating various input and providing facilities and infrastructure needed. Protecting means securing and defending the interest of weak people. In order to increase community participation in the decision-making process relating to themselves and community is an important element, such perspective will make community participation is tightly closed to the consolidation, culture and democracy experience.

According to Narayan (2002) there are many examples of empowerment approach initiated by poor people itself and by the government, civil society, and private sector. The successful effort to empower poor community increases their freedom from the option and practice in the different context; it is divided into four elements that also become community empowerment principle explained below:

Information Access Two-way information flowing from the government to the citizen and from citizen to the government is critical for a society that responsible, responsive from responsible government. Information Technology and Communication can play an important role in connecting poor people to the types of information, as is the case with each other and in the larger society. In order to make sure poor community's response, the government also adds the way to collect information on the options and priorities of the poor community. The mechanism for systematical feedback from them must be institutionalized.

Inclusion and Participation Inclusion focuses on the questions of who involved is. Participation refers to the question of how they are involved and what role they play when they are involved. An empowerment approach in the participation that sees the poor community as a co-producer with the authority and control of decisions and resources especially finance resources.

Accountability refers to the ability to call public officials, a private employee, or service provider to responsible, demands that they can answer about the policy, behavior, and the use of their fund.

Local organization capacity refers to the people's capacity to cooperate, organize them, and mobilize resource as the alternative of joint interest.

PNPM-MANDIRI PROSPEK Policy. According to Sumodiningrat (1998), poverty alleviation policy can be categorized into two, i.e. direct and indirect policy. The indirect policy includes the effort of creating tranquility and situation stability of economics, social and politics; controlling population; conserving living environment and preparing poor civil society through training activity. While direct policy includes: database development in determining target group; provision of basic needs (food, clothes, home, health, and education); the creation of working opportunity; regional development program; and credit 
service. Community poverty's condition viewed from the social and economics side is categorized very low including the provision of water and electricity as well as minimum infrastructure. Community living in the rural area is commonly having low background education, low status, and having no beneficial family structure. A large amount of definition of poverty mentions the difficult to decide the size of poverty since that level is different from one country to another, from one region to another in the same country.

In a legal standing way, the existence of PROSPEK is realized with the presence of Law Number 21 Year 2001 concerning Special Autonomy: Papua Governor Regulation Number 16 Year 2014 on the PROSPEK; Papua Governor's Decree Number 188.4/334/2014 regarding the Allocation of Budget for PROSPEK of allocation year 2014 and Mayor's Decree Number 116 Year 2014 on the Formation of Coordinator Team of Poverty Alleviation. That legal standing becomes an entry point of Jayapura Government to implement the policy of poverty alleviation through the PROSPEK. Papua province especially gives larger authority to the Papua Province, District/City Government in Papua and all the Papuan to regulate and manage them. In addition, the application of Special Autonomy actually wants to make a basic change from centralistic government system into decentralization government bureaucratic which is participative, democratic, transparent in accordance with the local people characteristic.

Any development program designed by Governor in which is in accordance with Rural Area PNPM Mandiri and supporting PBB MDGs (Millenium Development Goals) program by launching PROSPEK to manage:

1. There is still Papuan who are economically notable spread in villages but having local wisdom and its institution.

2. The implementation of Vision and Mission of Papua Governor with the slogan read "Papua Rises Up, Be Independent and Prosperous in 2018."

3. The implementation of the theme of the development Year 2014 is the first year of the leadership of Papua Governor Year 2013 until 2018 in which "strengthening local economics based local resources to reduce the gap between the region and the improvement of life quality.

\section{METHODS OF RESEARCH}

This research used qualitative approach research in which qualitative research is used to find, understand and get description clearly about the problem observed, study the phenomenon logically and disclose something behind the phenomenon and the problem being observed (Strauss \&amp; Corbin, 2003). The description of poverty alleviation implementation phenomenon in Jayapura has been carried out in a descriptive-qualitative and inductive way with the researchers role as the main actor in collecting data related to the study of poverty alleviation policy implementation through PROSPEK in South Jayapura District. The focus of this research was: 1) Program Implementation includes conformity between the program and the beneficiary (community), between the program and the implementing organization, and between the beneficiary and the implementing organization. Empowerment Implementation Program of PNPM-MANDIRI PROSPEK.

Any important program is a community as the decision maker in the rural area. While the executors in the sub-district level, district level, and so on more function as the guidance to facilitate and accompany the planning, execution, and responsibility of PNPM MANDIRI PROSPEK. The main executor (backbone) of PNPM MANDIRI-PROSPEK in rural level is TPKK (the Implementing Team of Village Activity) and PK (Village Facilitator) selected by society through village meeting. In addition, the ones becoming key informant are Mayor, Vice Mayor, Regional Secretary, Assistant 1 of Government, the Head of Government Office of Community and Village Governance Empowerment (BPMPK), Social Services Department, Local Government Agencies (SKPD). From these informants, the researchers collected the data both primary and secondary data.

The method or techniques to collect the data was observation, interview, and documentation. Validity data was checked by its a) credibility; b) transferability; 
c) dependability; d) conformability. Data analysis of this research refers to the interactive model by Miles et.al., (2014) stating that data analysis stage coversData Collection; Data Condensation; Data display and Conclusion drawing/verification. It is as indicated in the following table 2:

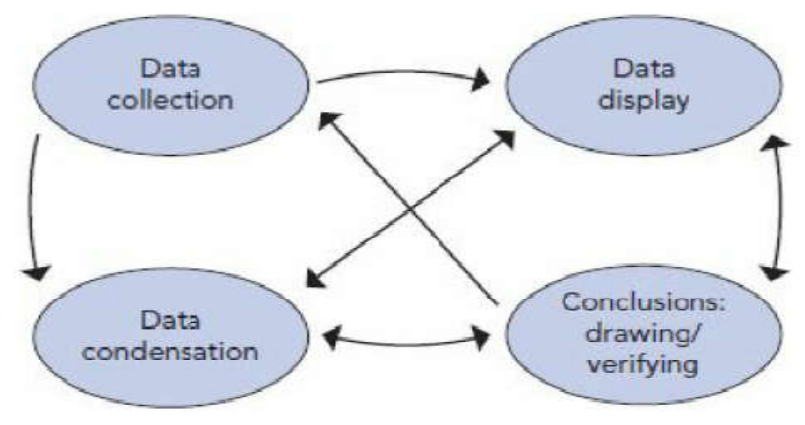

Figure 2- Data analysis of Interactive Model (Source: Miles et al., 2014)

\section{RESULTS AND DISCUSSION}

PNPM MANDIRI-PROSPEK Implementation. The research result, in relation to the relevance of PNPM-MANDIRI PROSPEK program offered to the beneficiary (Tahima Soroma and Tobati villagers of South Jayapura sub-district of Jayapura), shows the effort of adjustment of PNPM MANDIRI-PROSPEK program offered by what needed by the beneficiary of the program (target group). The fact of the research result described that the implementation of PNPM-MANDIRI PROSPEK was preceded by the implementation of Mandiri National Community Empowerment Program and Strategic Village Economic and Institutional Planning Program or PNPM MANDIRI-RESPEK under the focus of the program was the effort of fulfilling nutrition and food, education, health and the availability of facility and infrastructure in Tahima Soroma and Tobati village. Giving PNPM MANDIRI-RESPEK program has been considered successful so that the next step was being offered PNPM MANDIRI-PROSPEK with the focus of local economic development and capacity building of village institutional. That really represents the effort of program adjustment offered with the beneficiary needs, that is a community of Tahima Soroma and Tobati village of South Jayapura sub-district of Jayapura city of Papua Province. At the previous event was offered a similar program of nutrient and food fulfillment, education, health and the availability of basic facility and infrastructure, and then was changed by local economics development program and capacity building of village institutional.

Meanwhile, in relation to the program financing, the research result shows that the source of cost of PNPM MANDIRI-PROSPEK program comes from allocation and special autonomy cost of Papua Province whose management from Papua Government, moreover was allocated to all administrative regions of district/city of Papua Province. Started from budget year 2014/2015, program funds of PNPM MANDIRI-PROSPEK which previously was managed by Papua Government and its allocations was given directly to the head of village through the program of PNPM MANDIRI-PROSPEK under the focus of nutrient and food fulfillment, education, health and the avilability of facility and infrastructure, was then changed by Papua local government, in which the allocation of the fund was transferred into each of bank account of the district/city and at the same time become source of income of the Local Government of district/city being there in the administrative region of Papua Province.

The research result, in relation to the relevance of PNPM-MANDIRI PROSPEK to the implementing organization in Tahima Soroma and Tobati Village of South Jayapura subdistrict of Jayapura City, shows that the executor has had a capacity in performing the task that has been required by a program offered in the implementation of PNPM MANDIRIPROSPEK program. For that matter, in order to realize the relevance of the program to the executor, thus Central Government and Papua Local Government make a Memorandum of 
Understanding (MoU) as a legal basis in managing PNPM MANDIRI-PROSPEK. The initial data collection in relation to the implementation of PNPM-MANDIRI PROSPEK was conducted in the village area for pre-program socialization, identification of the candidate that comes in the sub-district meeting (MUSDIS), inform the schedule of MUDIS, make a sketch of a village consisted of related data; population; village category; potential and location of development as well as executor training, such as to; a). Implementing Team of Village Activity (TPKK); b). Village Facilitator; c). Proposal Writer Team; d). Verification Team; e). Village Meeting Body (BAMUS-KAM) and the Head of Village; f). Three Stovers Team; and g). Implementing Team of Sub-District Activity (TPKD)

The research result related to the relevance of beneficiary to the implementing organization of PNPM MANDIRI-PROSPEK shows that the requirement set by the implementing organization can be fulfilled by the beneficiary (target group) so that getting the output program expected by those two parties.

In relation to the beneficiary and the executor, it shows that procedure and requirement decided by the organization to be able to get program output to the beneficiary (community), to show that the mechanism of channeling and responsibility of financial help is like rigid and long but in a normative has become a system (value) to be obeyed so that become a real freedom that can be learnt to create efficiency and effectiveness in the implementation of PNPM MANDIRI-PROSPEK program.

According to the research result of those three relevance aspects above, it can be meant that if there is an adjustment among the three elements of policy implementation, program performance will be not a success as expected. If the output program is not in accordance with target group's need so its output clear target cannot be utilized. If the implementing organization has no ability to do the duty required by the program so that its organization cannot deliver the output program properly. If the requirement set by the implementing organization cannot be fulfilled by target group so that it will not get output program. That research result above, if seen from the perspective of theoretical, is in accordance with Korten's idea (as quoted in Tarigan, 2000) in which the adjustment model of policy or program implementation using learning process approach. Core in the intended model is the adjustment among the three elements within program implementation, that is the program itself, program implementation and program's target group. It is concluded that the implementation of PNPM MANDIRI-PROSPEK program in Tahima Soroma and Tobati Village of South Jayapura sub-district of Jayapura City, has had a relevance between the program, beneficiary and the implementing organization of PNPM MANDIRI-PROSPEK program preceded by policy implementation process symbolized by determining norm (value) in form of regulation (policy).

According to that analysis description of the research result, it can be arranged a minor proposition below:

Minor 1 proposition: "If There Is a program Adjustment, the Beneficiary and the Implementing Organization in the Program Implementation, thus Output Program can succeed and beneficial".

The implementation of community program empowerment through PNPM MANDIRIPROSPEK in Tahima Soromo and Tobati village of South Jayapura sub-district of Jayapura city represents the research result related to the principle application and community empowerment values in the effort of poverty alleviation through the program of PNPM MANDIRI-PROSPEK:

The research result shows that information access through the socialization of PNPM MANDIRI-PROSPEK was conducted openly by Jayapura government through related SKPD to all of the citizens of Jayapura, the implementation of the program was conducted by having related SKPD officials, Sub-district Head, the Head of Village and the representative of civil society. Program socialization implementation was also conducted through electronic media such as local television, local RRI broadcasting as well as printed media and website. All were conducted formally and structurally. Any group and facilitator role truly influence the information access of PNPM to the community so that more efficient and effective in providing understanding to the society. According to the research result above, if observed 
properly, it actually is in accordance with Narayan's (2002) idea which explains that the first principle in conducting empowerment is information access. Information access meant is the existence of two way information flowing from the government to citizen and from citizen to the government. Without having relevant and on time information as well as presented in an understandable way, it is impossible for the poor to take an effective action.

The research result conducted by the researchers is different with what Anyebe's (2014) result, that discusses the problem of policy development of Poverty Alleviation in Nigeria through National Poverty Eradication program. The research result shows that National Eradication Programme (NAPEP) as a policy intended to eradicate poverty extremely has noted limited success and continuously face a challenge of reality caused by bad coordination (access and information). For that matter, it was recommended so that the policy of National Poverty eradication programme (NAPEP) needs to be reviewed and redesigned to achieve more effective performance.

According to the analysis description of the research result and theoretical discourse and related concept of information access in the community empowerment, so that it can be arranged a minor proportion as follows:

Minor 2 Proposition: "If the principal access to information is government, facilitator, and village community in the program implementation maintained by all stakeholders, so that community empowerment can be achieved well".

This inclusion and participation aspect is based on the research result that the application of community empowerment principle has been conducted well by not comparing society in participating, all community has a chance to participate. Even though the program budget was limited, but the community independently has been able to develop donation both in form of money or goods. Therefore, that mechanism brings many societies which can participate in the implementation of PNPM MANDIRI-PROSPEK. Any community who are allowed to directly participate has a group and business potential that can be developed, while the community member who has not group and a business is directly scouted by a group who has had a group an business to be able to become group member and is involved in a business that has been run so that indirectly all community member participate in the implementation of PNPM MANDIRI-PROSPEK. Moreover, all community members getting program assistance of PNPM MANDIRI-PROSPEK participate through a discussion in every meeting conducted by each group leader who is commonly attended by facilitator or the representative from sub-district government and local directly, that situation was used as a facility or media to discuss to ask all things related to the process and implementation of PNPM MANDIRI-PROSPEK as one of the manifestations of commitment of Jayapura government in conducting community empowerment.

The research result above has answered inclusion concept focusing on the question who empowered is, while participation focusing on how they are empowered and what role they play after being part of group empowered. This research result supports the study conducted by Darwanto (2003) and Narayan (2002) stating that elements from empowerment do not separate from inclusion and participation aspect. Moreover, Sumodingrat (1998) explained that participation as one of the development elements is an adaptation process of the community to the running changes. For that matter, participation has a significant position in the development. Therefore, it can be compiled a minor proposition as follows:

Minor 3 proposition: "If the principle of inclusion and participation in the implementation program was grown by all stakeholders, so that community empowerment can be achieved well".

The research result discloses that implementation accountability of PNPM MANDIRIPROSPEK has been grown and performed well by civil society getting the help of PNPM MANDIRI-PROSPEK group in form of either money or goods in running the business. Accountability is proven by the written report of the donation acceptance, business development, and group member of beneficiary delivered through a facilitator, later on, the facilitator says it to the related SKPD. After that was being done monev to assess the success of the program. Later on, Japayura Local Government delivers the report both in 
accounting terms and program development to all of the related stakeholders in Jayapura or Papua Province Government.

The research result above reflected the obligations of individuals or employer trusted to manage program assistance of PNPM MANDIRI-PROSPEK and the related to be able to answer something related to the responsibility. Accountability is tightly related to the instrument for control activity especially in terms of achievement of program implementation result and deliver it transparently to the community. While the public accountant concept is also related to the obligation to explain and answer questions on what have been going, and planned will be conducted by public sector organization (Mahmudi, 2002). Taking a close look theory discourse and accountability concept, if related to the research result stating that the accountability of PNPM MANDIRI-PROSPEK implementation has had an adjustment with the research result and theory and concept of accountability in the concept of the accountability program. According to the description research result analysis and theoretical discourse as well as the related concept of accountability principle application in the community empowerment so that can be arranged a minor proposition as follows:

Minor 4 proposition: "If accountability Principle in the program implementation is applied well, so that community empowerment is achieved well".

Of this aspect, every business group has a different capacity. There is a group that still needs management training so that able to develop its business group so that able to overcome faced problems, in addition, is also there is a business group that has been developed so that has been a business entity in form of cooperative. Jayapura city government in developing local organization capacity has conducted comparative study and training, as well as guidance aims to improve the quality of human resources of farmer group, fisherman group of cage fish farming, livestock farmer group and creative economy group both living in Tahima Soroma Village and in Tobati Village of South Jayapura Subdistrict of Jayapura City. Local organization capacity is grown by conducting organization to the groups in the community at the low level (such as woman group, youth group, farmer group), and to the public figure, traditional leaders, religious leaders, sub-district or village officials.

Capacity strengthening is a process to increase or change individual behavior, organization, and community system in achieving the determined goal efficiently and effectively. According to the research result, local organization capacity application in the implementation of PNPM-MANDIRI PROSPEK for community empowerment also determine the success of empowerment for society through PNPM-MANDIRI PROSPEK. For that matter, it can be arranged a minor proposition below:

Minor 5 Proposition: "If the principle of local organization capacity is fulfilled correctly in the program implementation so that community empowerment can be achieved well".

\section{CONCLUSION}

The implementation of PNPM MANDIRI-PROSPEK has indicated a relevance of the program to the beneficiary (Community), of the program to the implementing organization and of the beneficiary to the implementing organization. Output program has been in accordance with the needs of target group showing that output program can be utilized well. The implementing organization has had an ability to perform the duty required by the program so that the implementing organization can present the output program correctly. Requirements and procedure determined by the implementing organization can be fulfilled by target group (beneficiary) so that the beneficiary obtains output program in form of both economic development and village institutional building as an effort of poverty alleviation especially in Tahima Soroma and Tobati Village of South Jayapura Sub-district of Papua Province. The implementation of community empowerment program through PNPM MANDIRI-PROSPEK under the application of principle/empowerment values include: a) information access realized by the activity of open socialization to SKPD/SATKER and all community, as well as there is two-way discussion between the government, facilitator, and villagers; b) community inclusion and participation who are able to participate directly must 
have a group and potential that can be developed. However, the community inclusively is able to participate indirectly; c) accountability is signed by the written report since the donation acceptance, business development, and member group of beneficiary delivered through guidance, and then propose it to the related SKPD/SATKER. After applying monev to assess the success of the program; d) local organization capacity and the implementation of PNPM MANDIRI-PROSPEK have a capacity difference between the arranged group and the new one so that the government makes an improved capacity of the implementing organization of PNPM MANDIRI-PROSPEK through training and guidance.

This research result can encourage Jayapura City Government to keep the supporting factor of the success of the policy of PNPM MANDIRI-PROSPEK, such as the existence of facilitator in every sub-district level, community enthusiasm in performing PNPM MANDIRIPROSPEK. That is able to anticipate or minimize the inhibiting factors of PNPM MANDIRIPROSPEK policies, such as the realities of community members who are still difficult to accept changes and limited budgets and program scope, as well as discontinuities, program disinformation, disorientation, a bureaucratic range related to the implementation of PNPM MANDIRI-PROSPEK policy.

\section{REFERENCES}

1. Anyebe, A.A. (2014). Nigerian University and Manpower Development in a Changing World. Higher Education Studies, 4 (1), 82-93.

2. Bratakusumah, D., \& Irawati, E. (2005). The Continuing Search for Citizen Participation in Policy Making Process. Citizen Empowerment Through Participation. Asian Development Bank and Network of Asia Pacific Schools and Institutes of Public Administration and Governance (NAPSIPAG). Kuala Lumpur: Malaysia.

3. Bevir, M. (ed.) (2007). Editor's Introduction: What is Governance?. Public Governance, London, Sage, 1, 21-33.

4. Darwanto.(2003). Econometric Analysis of Indonesian Rice Economy and Policy. Gajah Mada University Press, Yogyakarta, 185-204.

5. Edward III., \& George, C. (1984). Public Policy Implementing. Jai Press Inc, LondonEngland (edited).

6. Efendi, T. N. (1993). Sumber Daya Manusia, Peluang Kerja dan Kemiskinan. Yogyakarta: PT Tiara Wacana.

7. Giddens, A. (1984). The Constitution of Society: Outline of the Theory of Structuration. University of California Press. United States

8. Hogwood, B. W., \& Lewis A. G. (1984). Policy Analysis for the Real World, oxford University Press.

9. Kuncoro, M. (1997). Ekonomi Pembangunan, Teori, masalah dan kebijakan. Cetakan pertama. Yogyakarta: YKPN.

10. Larrain, J.(1994). The Postmodern Critique of Ideology. The Sociological Review, 42 (2).

11. Mahmudi. (2002).Laporan Keuangan Sektor Publik Untuk Transparansi Dan Akuntabilitas Publik. Jurnal Pendidikan Akuntansi (JPAI). Yogyakarta.

12. Miles, M. B., Huberman, M., Saldaña, J. (2014). Qualitative data analysis: a methods source book. Third edition. Arizona State University. SAGE Publications, Inc.

13. Mochtar, M. (1993). Perbandingan Sistem Politik. Yogyakarta: UGM Press.

14. Narayan, D. (2002). Empowerment and Poverty Reduction. World Bank.

15. Nugroho, I., \& Dahuri, R. (2004). Pembangunan Wilayah-Perspektif Ekonomi, Sosial dan Lingkungan. Jakarta: Pustaka LP3ES.

16. Peters, M.A. (2001). Poststructuralism, Marxism, and Neoliberalisme: between theory and politics. Rowman \& Littlefield Publishers.

17. Ploeg, J.D. van der \& A. Long. (1994). Born from within: practice and perspectives of endogenous rural development. Van Gorcum. Assen

18. Siagian, S.P.(1983). Administrasi Pembangunan. Jakarta: Gunung Agung.

19. Subarsono. (2005). Analisis Kebijakan Publik Konsep, Teori dan Aplikasi. Yogyakarta: Pustaka Pelajar. 
20. Suharto. (2006). Membangun Masyarakat Memberdayakan Rakyat. Bandung: PT.Refika Aditama.

21. Sumaryadi, I.N. (2005). Perencanaan Pembangunan Daerah Otonom dan Pemberdayaan Masyarakat. Penerbit Citra Utama.

22. Sumodiningrat, G.(1998). Membangun Perekonomian Rakyat. Pustaka Pelajar. Yogyakarta.

23. Strauss, A. L. (2003). Basic of Qualitative Research. London: Sage Publication.

24. Tachjan. (2006). Implementasi Kebijakan Publik. Bandung: Penerbit AIPI Bandung. Puslit KP2W Lemlit UNPAD.

25. Tarigan, A. (2000). Implementasi Kebijakan Jaring Pengaman Sosial. Unpublished Thesis. Yogyakarta: PPs UGM Yogyakarta.

26. Wahab, S.A.(2002). Analisis Kebijaksanaan, Dari Formulasi ke Implementasi Kebijaksanaan Negara. Jakarta: Bumi Aksara.

27. Wibawa, S.(1994). Evaluasi Kebijakan Publik. Jakarta: PT Raja Grafindo Persada.

28. World Bank. (2002). Globalisation, growth, and poverty: building an inclusive world economy, a co publication of the World Bank and Oxford University Press. New York: Oxford University Press. 